\title{
Fueling Education Reform: Historically Black Colleges Are Meeting a National Science Imperative
}

\author{
Steve Suitts
}

\author{
Southern Education Foundation, 135 Auburn Avenue, 2nd Floor, Atlanta, Georgia 30303
}

Submitted July 2, 2003; Accepted July 3, 2003

Historically black colleges and universities (HBCUs) are playing a critical role today in helping America overcome a looming shortage of scientists and engineers who are vital to the nation's future economic growth and competitiveness. Despite meager funding and a lack of public recognition, these educational institutions are producing a large share of the nation's African American graduates in the fields of science, technology, engineering, and mathematics (STEM).

The shortage in human capital in the sciences and related fields in the United States is becoming quite evident in the education pipeline. In recent years, for example, the numbers of students both receiving bachelor degrees and going into graduate school in most STEM fields have declined sharply compared to those in the previous decade. The drop is as much as 22 to $26 \%$ for students receiving bachelor degrees in computer science and math (ETS, 2002; AAAS, 2002).

At the same time, nearly $70 \%$ of the growth in the numbers of young adults between 18 and 24 years of age is among minorities, including a $19 \%$ increase in the number of African Americans (Congressional Commission on the Advancement of Women and Minorities in Science, Engineering and Technology Development, 2000; ETS, 2002). These and related demographic trends illuminate a clear national mandate: America must educate and train larger numbers of students of color if it is to meet the nation's future needs for additional scientists.

HBCUs are helping to meet this challenge. Established following the Civil War to help African Americans gain access to education, for over 80 years HBCUs were the only places in the American South where African Americans could receive a higher education. Today they are still making a major contribution toward black higher education in America. In 2000, for example, almost one of every four African Americans who earned a bachelor's degree in the United States graduated from one of fewer than 100 HBCUs (NSF, 2002).

In the sciences, HBCUs are playing an even larger role today. In 2000, they graduated $40 \%$ of the black students in America who received a bachelor's degree in biological science. They were responsible for more than $40 \%$ of all black students in America who received degrees in physical sciencesphysics, chemistry, astronomy, environmental sciences-and mathematics (NSF, 2002). In almost every STEM field, HBCUs

DOI: $10.1187 /$ cbe.03-07-0032

Corresponding author. E-mail address: ssuitts@sefatl.org. lead the nation's larger, much more resourceful universities in producing black graduates (NSF, 2000, 2002; The Top 100, 2002). In addition, a National Science Foundation (NSF) study suggests that African Americans who graduate from HBCU undergraduate institutions in the sciences are more likely to go to graduate school and complete their doctoral degrees than African Americans from other institutions (NSF, 2000).

Despite this important national role, $\mathrm{HBCUs}$ receive relatively meager support. During the 1990s, for instance, HBCUs received less than $2 \%$ of the total amount $-\$ 140$ billion-in federal grants awarded to America's institutions of higher education for science and engineering programs (NSF, 2001; Quality Education for Minorities Network, 2002). In addition, federal funds for science and science education at HBCUs are often categorical and made inflexible by congressional mandates (NSF, 1999). Investments by private foundations in STEM are comparatively small-and recently in decline. HBCUs are the focus of very few private foundations and only a handful has given regularly to support science education or science programs at HBCUs (see National Academy of Sciences, 2001; Foundation Center, 2002).

A number of factors contribute to this neglect of HBCUs. Many foundations support institutions that operate only in a particular geographic region or place, and many do not include the South, where most HBCUs are located. In research competitions, HBCUs often have difficulty competing with large, well-financed traditionally white institutions. Mutually beneficial partnerships between traditionally white institutions and HBCUs are not commonplace (see AAAS, 2001). Moreover, there is comparatively little giving among private foundations for science education, and even less focused on the education of African Americans and other minority groups in STEM fields in high school and college.

Some efforts supporting HBCUs' central role in the STEM fields have shown considerable promise. For example, since 1998 the NSF has maintained the HBCU-UP program $^{1}$ as a way to provide institutional support for a wide range of activities including planning, faculty and course development, equipment, and precollege bridge programs. It also allows for multiyear funding. Another noteworthy program is the National Institute of Health's U-STAR programUndergraduate Student Training in Academic Research. ${ }^{2}$ It

\footnotetext{
${ }^{1}$ http://www.her.nsf.gov/hrd/hbcu.asp.

${ }^{2}$ http://www.nigms.nih.gov/minority/marc.html.
} 
has been a relatively open-ended program supporting a variety of needs and initiatives in several biology departments at HBCUs.

Yet as funding sources supporting an HBCU's comprehensive institutional needs for undergraduate education in the sciences, these programs are the exception. Both also have relatively tiny budgets. NSF's HBCU-UP program, for instance, has had an average budget of $\$ 10$ million a year since it began 6 years ago.

Against the odds, $\mathrm{HBCUs}^{3}$ have proven that they are ready and able to increase African-American graduates in the sciences. The nation now must invest more in science and science education programs at HBCUs. Scientists in all disciplines at traditionally white universities and public facilities should look for new ways to build mutually beneficial partnerships with HBCUs and to expand opportunities for HBCU undergraduates to have "graduate-level " internships during summers. These efforts will benefit HBCUs and their students, but equally importantly, they will build future potential for the nation's economic growth and for the vitality of the science communities.

\section{REFERENCES}

American Association for the Advancement of Science (AAAS). (2001). In Pursuit of a Diverse Science, Technology, Engineering, and Mathematics Workforce: Recommended Research Priorities to Enhance Participation by Underrepresented Minorities, Washington, DC: AAAS.

American Association for the Advancement of Science (AAAS). (2002). Losing Ground: Science and Engineering Graduate Education of Black and Hispanic Americans, Washington, DC: AAAS. (A summary is available on-line at http://ehrweb.aaas.org/her/exec.html).

The top 100: Interpreting the data. (2002, June 20). Black Issues in Higher Education 19(9), 40-122.

Congressional Commission on the Advancement of Women and Minorities in Science, Engineering and Technology Development. (2000). Land of Plenty, Diversity as America's Competitive Edge in Science, Engineering and Technology, Washington, DC: Congressional Commission.

Educational Testing Service (ETS). (2002). Meeting the Need for Scientists, Engineers, and an Educated Citizenry in a Technological Society, Princeton, NJ: ETS.

Foundation Center. (2002). Highlights of the Foundation Center's Foundation Giving Trends. Foundations Today Series, Washington, $D C$ : Foundation Center.

National Academy of Sciences. (2001). Trends in nonfederal support of research. In: Trends in Federal Support of Research and Graduate Education, Washington, DC: NAS, 79-83.

National Science Foundation (NSF). (1999). What is the level of federal science and engineering support to historically black colleges and universities? Issue Brief NSF 99-356, Arlington, VA: NSF.

National Science Foundation (NSF). (2000). Women, Minorities, and Persons with Disabilities in Science and Engineering: 2000, Arlington, VA: NSF.

National Science Foundation (NSF). (2002). Science and engineering degrees, by race/ethnicity of recipients: 1991-2002. NSF 02-329, Arlington, VA: NSF.

Quality Education for Minorities (QEM) Network. (2002). Facts and Figures: Federal Support for Science and Engineering at Minority Serving Institutions of Higher Education, Washington, DC: QEM Network.

\footnotetext{
${ }^{3} \mathrm{~A}$ list of HBCUs with links to each campus is available at http:// www.ed.gov/inits/commissionsboards/whhbcu/list.html.
} 